\title{
特集—配列ナノ空間物質の高圧科学
}

\section{配列ナノ空間物質の高圧挙動に対する ヘリウム準静水圧の効果}

\author{
Effect of Helium Quasi-Hydrostatic Pressure on High-Pressure \\ Behavior of Some Materials with Nano Spaces
}

\section{中野 智志}

Satoshi NAKANO

\begin{abstract}
The pressure effects of physical/chemical properties of a material are important to realize a relationship between its structure and the properties. Characteristic properties exhibited in some materials with nano spaces are particularly affected by pressure because the densification occurs selectively around the porous or weak-bonded portions in their structures. However, pressure distribution and shear stress often hides a critical phenomenon caused by pressure. Highly hydrostatic helium pressure medium can solve the problem and provide high quality experimental data. This report introduces some experimental examples, a high-pressure Raman scattering spectroscopy on $\alpha$-boron and a powder $\mathrm{x}$-ray diffraction study on type-I' Ge-clathrate $\mathrm{Ba}_{24} \mathrm{Ge}_{100}$, using the helium pressure.
\end{abstract}

[regulated nano space, high-pressure, hydrostatic pressure, $x$-ray diffraction, Raman scattering spectroscopy]

\section{1. はじめに}

一般に，高圧下に置かれた物質はより高密度な状 態へと推移し，構造相転移を起こせばより対称性の 高い構造へと向かう。しかし，結合の弱い方位や空 間を内包し構造的異方性の大きな物質においては, 圧力印加による構造変化やそれに伴う物性変化は複 雑である。局所的に大きな圧縮を起こし，そのため に物性值に特異な変化が現れるほか, 局所的な反応 を引き起こすケースもある。例えば，層状水酸化物 は圧力により層内よりも層間が選択的に圧縮され， 層間に水素結合があれば水素結合対象化が起こるこ とで, 軸比変化の圧力依存性や物性に変化が現れる [1]。また, 可視光領域で光吸収・発光を示す無機 有機複合半導体は導電性ペロブスカイト格子と絶縁 性有機分子層で構成されるが, 圧力印加はペロブス カイト格子の骨格を維持しながら有機分子層を選択 的に圧縮し, 発光エネルギーを自在にコントロール

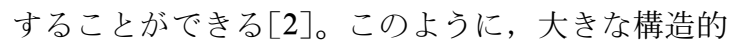
異方性を持つ物質は, 加圧による局所的な再配列や
物性変化により，圧力チューニングが効果的な物質 であるとも言える。物質の物性の発現メカニズムを 考察する際, 圧力印加による物性変化は重要な情報 となる。

一方，一言で圧力と言っても，動的圧力や静的圧 力, 剪断応力や圧力分布の問題など, そこには様々 な多様性がある。それらの圧力の「質」は物質挙動 にも影響し，これらの複合環境下で行われている通 常の高圧実験では, 物質が示す挙動のクリティカ ル・ポイントを見極めにくくなることもある。固体 ヨウ素の圧力誘起分子解離に抢いて，ヘリウム準静 水圧下の X 線回折で, 分子性固体と原子性固体の 中間構造として過渡的な変調構造が観測されたこと [3]も，そのような圧力の「質」を単純化した結果 と言うことができる。構造異方性を大きく持つ配列 ナノ空間物質は，なおのことこのような圧力の「質」 の影響を受けやすく，この複雑さを排除しなければ， 高圧下で起こる特異な構造変化や物性挙動のポイン トが見極めにくい。静水圧性の高い圧力媒体を用い,

テ305-0044 茨城県つくば市並木 1-1 物質・材料研究機構 先端材料プロセスユニット 超高圧グループ

National Institute for Materials Science (NIMS), 1-1 Namiki, Tsukuba, Ibaraki 305-0044

Electronic address: nakano.satoshi@nims.go.jp 
試料室内の圧力分布や一軸圧縮下での剪断応力を解 消することは，このような複雑さを排除するための 手段として有効である。

ここでは, 特異な物性を発現する配列ナノ空間物 質の構造と物性を理解する研究として，ヘリウム圧 力媒体を用いた準静水圧環境で精密な測定を行うこ とで現れてきた，いくつかの結果を報告する。

\section{2. $\mathrm{B}_{12}$ 正二十面体クラスター物質 $\alpha$-boron の高圧}

\section{ラマン散乱分光}

\section{1 ホウ素クラスター物質と圧力誘起現象}

単体ホウ素の 1 つである $\alpha$-boron は, $\mathrm{B}_{12}$ 正二十 面体 (icosahedron) クラスターがほぼ六方最密構 造に配列した, 極めて単純な菱面体晶構造をしてい る。高硬度物質として知られる $\mathrm{B}_{4} \mathrm{C}$ や $\mathrm{B}_{6} \mathrm{O}$ は, こ の $\mathrm{B}_{12}$ 正二十面体を連結する原子として $\mathrm{C}$ や O が 結合に関与している。また, 一連の水素化ホウ素 （ボラン類）は $\mathrm{B}_{12}$ 正二十面体の一部が久損して水 素化した誘導体として構造を理解することができる。 もう一つの単体ホウ素である $\beta$-boron はより複雑な 構造を持つが, 基本的には $\mathrm{B}_{84}$ や $\mathrm{B}_{10}$ をユニットと するクラスター化合物である。また，多ホウ化合物 の多くも類似のホウ素クラスターを基本構造に持つ。 このように, 単体ホウ素抢よびホウ化物の構造と物 性の関連を理解する上で, その単位構造となるホウ 素クラスターの挙動は重要である。

高圧下に抢けるホウ素の物性で大きな注目を浴び たのは, $\beta$-boronの超伝導発現である $[4]$ 。 $\beta$-boron の電気抵抗は圧力とともに減少し, 30-40 GPa 付近 で一度変化の少ない anomaly が見られた後に再び 減少し, 約 $160 \mathrm{GPa}$ で超伝導転移が観測された。

$\alpha$-boron は $\beta$-boronよりもはるかに単純な構造で あるため, ホウ素クラスターが物性に及ぼす影響を 検討しやすい。 $\alpha$-boron も $\beta$-boron と同様に, 30$50 \mathrm{GPa}$ 付近で電気抵抗の圧力变化に anomaly が見 られた後, ほぼ同じ圧力（約 $159 \mathrm{GPa}$ ）で超伝導転

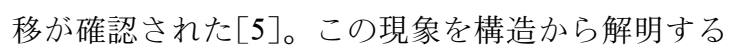
ために高圧 X 線回折測定が行われ, 約 $40 \mathrm{GPa}$ で $\mathrm{B}_{12}$ 正二十面体が歪んでいる可能性が報告され，30 $-40 \mathrm{GPa}$ 付近で現れる電気抵抗の anomaly との関

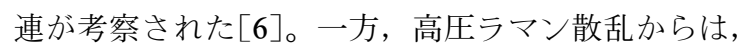
約 $80 \mathrm{GPa}$ まで特異な変化は見られていない[7]。 しかしながら,これらの X 線回折パターンとラマ ン散乱スペクトルはあまりシャープなものではなく, 何らかの情報が埋もれて見えていない可能性がある。

\section{2 ヘリウム圧力媒体を用いた $\alpha$-boron の高圧ラ}

\section{マン散乱分光}

$\alpha$-boron のような硬い物質は，高圧下で粒子同士 が接触すると歪みを開放せず，ブロードな回折パ ターンやスペクトルを示すことが少なくない。静水 圧性に配慮した実験構成は，それをできるだけ緩和 する方向に働き，より良質なデータを得られる可能 性がある。そこで, 圧力媒体にへリウムを用いた高 圧ラマン散乱測定を行った。

高圧装置にはダイヤモンド・アンビル・セル （DAC）を用い，試料と圧力マーカーのルビー球を セットした試料室に, 圧力媒体として $180 \mathrm{MPa}$ の ヘリウムを充填した $[8]$ 。ルビー蛍光とラマン散乱 スペクトルは，アルゴンイオンレーザーの $514.5 \mathrm{~nm}$ 線を励起光として用い, Jobin Yvon/愛宕 物産製 T64000 のシングル・モノクロメーターで測 定した。ラマン散乱測定の典型的なレーザー強度は 入射直前で約 $10 \mathrm{~mW}$, 照射ビーム径は試料位置で 約 $10 \mu \mathrm{m}$, 後方散乱測定を行った。得られたスペク トルから，各ピークを中間ローレンツ関数でフィッ ティングし，ピーク位置とピーク積分強度の圧力依 存性を調べた。

ラマン散乱スペクトルの圧力変化を Fig. 1 に示 す。測定最高圧約 $55 \mathrm{GPa}$ まで顕著なブロードニン グなどは起こっておらず，静水圧性の高いヘリウム 圧力媒体を用いた効果が現れていると考えられる。

Fig. 2 にピーク位置の圧力依存性を示す。ほとん どのピークが圧力上昇とともに滑らかに高波数シフ トして抢り, 電気抵抗変化の anomaly が見られた 30-40 GPa 付近でも，特段の変化は見られない。そ の中で, $520 \mathrm{~cm}^{-1}$ 付近のピークは異なった傾向を 見せ，約 $20 \mathrm{GPa}$ を境界に高波数シフトから低波数 シフトへと変化している。この $520 \mathrm{~cm}^{-1}$ 付近の ピークは $\mathrm{B}_{12}$ 二十面体の回転振動に対応する librational モードで, 他のピークに比較してとりわけシ ヤープなピークとなり，これが圧力とともにソフト 化する傾向を示すことは，既に報告されている $[7]$ 。 今回の測定では, その librational モードのソフト化 が見られる圧力以上で, 約 $570 \mathrm{~cm}^{-1} に$ 新たなブ ロードなピークが観察された。このピークの由来は 未だ明らかでないが， $\mathrm{B}_{12}$ 二十面体同士の相互作用 により新たなモードが生じた可能性が考えられる。

Fig. 3 には全ピーク強度の和で規格化した各ピー ク強度の圧力依存性を示した。この中で特に注目す べき点は， $\alpha$-boronのラマンスペクトルの中で強度 


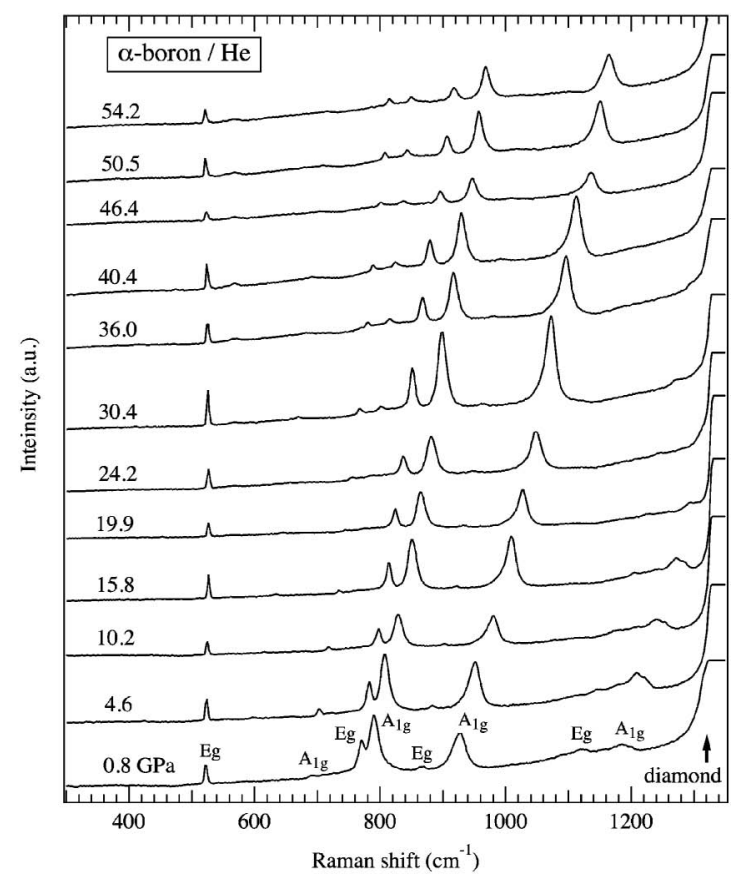

Fig. 1. Raman spectra of $\alpha$-boron with a helium pressure medium in various pressures.

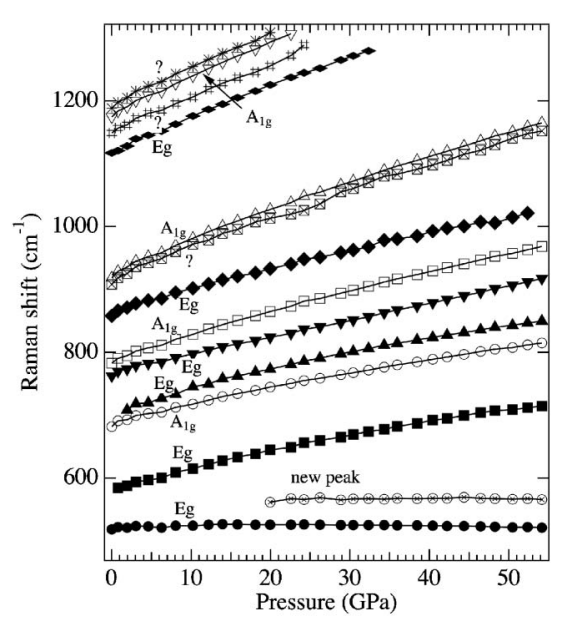

Fig. 2. Raman peak positions of $\alpha$-boron in a function of pressure.

の大きい二つの $\mathrm{A}_{1 \mathrm{~g}}$ ピーク（常圧で約 $790 \mathrm{~cm}^{-1}$ お よび約 $\left.920 \mathrm{~cm}^{-1}\right)$ が，いずれも強度変化の圧力依 存性を $40 \mathrm{GPa}$ 付近で逆転させていることである。 この二つのピークは, いずれも $\mathrm{B}_{12}$ 正二十面体の膨 張・収縮の振動を表す breathing モードによるピー クである。ラマン散乱強度は, 一般的に始状態が遷

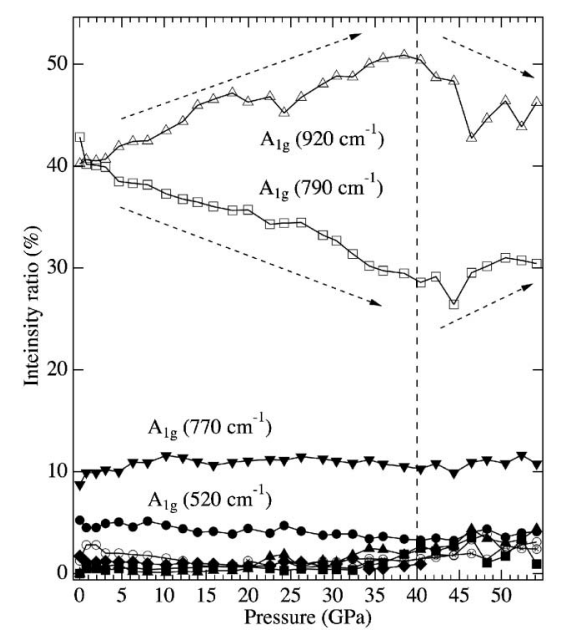

Fig. 3. Normalized intensity ratio of Raman peaks of $\alpha$ boron in a function of pressure. The wavenumber in the parenthesis appended to each peak shows the wavenumber in which the peak is observed at ambient pressure.

移してラマン散乱を起こす確率と始状態の確率の積 であるということができるが，該当する振動の周辺 構造に大きく関係する。breathing モードのピーク 強度の圧力変化が $40 \mathrm{GPa}$ 付近で逆転したことは, $\mathrm{B}_{12}$ 正二十面体の周辺構造の圧力変化が, $40 \mathrm{GPa}$ 付近を境に反転したことを意味している。

Shirai らは $\alpha$-boronの構造の圧力変化を第一原理 計算加ら検討し， $\alpha$-boronの菱面体晶の軸角 $\alpha_{\mathrm{th}}$ は 加圧当初は減少していくが， $30 \mathrm{GPa}$ を越えるとそ れが逆転し, 圧力とともに拡大していくことを示し た [9]。これは， $\alpha$-boron が $\mathrm{B}_{12}$ 正二十面体クラス ターが配列した特異な菱面体晶構造をしているため と考えられ， $\mathrm{B}_{12}$ 正二十面体同士の相互作用により このような逆転現象が起こると推察される。今回の ラマン散乱スペクトルで現れた, librational モード のソフト化に対応して現れるブロードなピークの存 在や, breathing モードの強度の圧力変化が逆転す る現象などは, Shirai らによる第一原理計算の結果 に対応したものと考えられる。

これまでの高圧 X 線回折やラマン散乱測定の結 果からは類似の傾向は明瞭には見られないが，これ は静水圧性の問題などによるデータの質が阻害要因 になっている可能性がある。今回得られた結果は, ヘリウム圧力媒体の効果によるものと考えられる。 


\section{3. 構造 I'型クラスレート $\mathrm{Ba}_{24} \mathrm{Ge}_{100}$ の粉末高圧 $\mathrm{X}$ 線回折}

3.1 構造 I'型クラスレート $\mathrm{Ba}_{24} \mathrm{Si}_{100}$ と $\mathrm{Ba}_{24} \mathrm{Ge}_{100}$ の構造亡物性

Ba イオンを内包する構造 I'型クラスレートであ る $\mathrm{Ba}_{24} \mathrm{Si}_{100}$ と $\mathrm{Ba}_{24} \mathrm{Ge}_{100}$ は, 同じ構造をとるが物性 には違いが多い。 $\mathrm{Ba}_{24} \mathrm{Si}_{100}$ は常圧で $T_{\mathrm{c}}=1.4 \mathrm{~K}$ の超 伝導体であるが，体積が約 $11 \%$ 大きい $\mathrm{Ba}_{24} \mathrm{Ge}_{100}$ は $\mathrm{Ba}_{24} \mathrm{Si}_{100}$ よりも低い超伝導転移温度を示す $\left(T_{\mathrm{c}}=0.24 \mathrm{~K}\right)[10]$ 。また, $\mathrm{Ba}_{24} \mathrm{Ge}_{100}$ は温度 $T_{\mathrm{s} 1}$ お よび $T_{\mathrm{s} 2}$ （常圧ではそれぞれ $225 \mathrm{~K}$ および $175 \mathrm{~K}$ )

で $\mathrm{Ba}_{24} \mathrm{Si}_{100}$ には見られない低抵抗金属相から高抵 抗金属相への相転移を起こし $[11]$, これは格子定数 や磁化率の温度依存性に anomaly が現れることで 確認されている[12］。この差は, ケージサイズの違 いによりケージ内 Ba イオンのラットリング挙動が 異なるためと説明されており, X 線回折測定デー タによる MEM 解析からも, $\mathrm{Ba}_{24} \mathrm{Ge}_{100}$ では三種類 ある Ba イオンのうち, open cage にある $\mathrm{Ba}(3)$ が $80 \mathrm{~K}$ で非対称的なラットリング振動をしているこ とが示された $[13]$ 。

電子ーフォノン相互作用により発現するクラス レートの物性を理解するために, 高圧下でケージサ イズを変化させ，物性変化を測定することは重要な 情報を与える。 $\mathrm{Ba}_{24} \mathrm{Si}_{100}$ は圧力の上昇とともに $T_{\mathrm{c}}$ が低下するが, $\mathrm{Ba}_{24} \mathrm{Ge}_{100}$ は $200 \mathrm{~K}$ 付近での相転移 が抑制されるとともに，逆に $T_{\mathrm{c}}$ が上昇する $\left(2.7 \mathrm{GPa}\right.$ で $\left.T_{\mathrm{c}}=3.8 \mathrm{~K}\right)[14] 。 \mathrm{Ba}_{24} \mathrm{Ge}_{100}$ の $T_{\mathrm{c}}$ が高 圧下で上昇する理由は, $\mathrm{Ge}$ ケージ中の $\mathrm{Ba}$ イオン のラットリング挙動が引き起こす結晶構造の歪久を 圧力が抑制して対称性を保ち, フェルミ準位の状態 密度を高く保つためと説明されている。Shimizu ら は高圧ラマン散乱を行い, Ge ケージに起因するラ マンモードの一つが $3.2 \mathrm{GPa}$ 以上でスプリットす ることから， Ba-Ge 相互作用に起因した構造の歪 みによる相転移を指摘した $[15]$ 。

しかし, 構造情報を得るにはX 線回折実験が有 効である。その際, わずかな格子定数变化や物性変 化しか示さない微妙な構造変化を観測するには, 静 水圧性の高く均一な圧力場で測定が行われる必要が ある。ここでは, へリウム圧力媒体を用いた $\mathrm{Ba}_{24} \mathrm{Ge}_{100}$ の室温高圧 $\mathrm{X}$ 線回折実験々低温高圧 $\mathrm{X}$ 線 回折実験の例を示す。

\section{$3.2 \mathrm{Ba}_{24} \mathrm{Ge}_{100}$ の室温高圧 X 線回折測定}

高圧装置には DAC, 圧力媒体には $180 \mathrm{MPa} の へ$
リウムを充填し, 約 $35 \mathrm{GPa}$ まで加圧した。高圧 X 線回折実験は KEK-PF BL-18C で $E=20 \mathrm{keV}$ の単 色 $\mathrm{X}$ 線を用いて行った。圧力值はルビー蛍光の R1 ピークをガウス関数でフィッティングすることで求 め, その誤差は常圧標準ルビーと試料室内ルビーの フィッティングによるそれぞれの標準偏差を加重し て求めた。高圧下での $\mathrm{Ba}_{24} \mathrm{Ge}_{100}$ の単位胞体積抢よ びその誤差は, 回折パターンの代表的な 13 本の回 折ピークをそれぞれ Pearson VII 関数でカーブフィ ットして格子定数を計算し, その平均と標準偏差か ら求めた。

Fig. 4 に得られた回折パターンの一例を示す。常 圧から約 $10 \mathrm{GPa}$ まで基本的な構造に大きな変化は 見られないが，10 GPa を越えるとピークのブロー ド化が起こり, 約 $35 \mathrm{GPa}$ では数本のブロードな ピークが観察されるのみであった。これは「圧力誘 起アモルファス化」と呼ばれる現象に類似している が，再び常圧に戻すと出発時の回折パターンへとほ ぼ完全に回復し, ピークの半值幅にもほとんど変化 がない。このような現象はクラスレートの圧力誘起 現象でしばしば見られて抢り [16]，アモルファス化 ではなく, 元の構造の結合を一定程度維持したま女 長周期秩序の乱れが生じているものと考えられる。 今回の $\mathrm{Ba}_{24} \mathrm{Ge}_{100}$ の場合は, 回折パターンで $d=2.4$ $\sim 2.5 \AA$ 付近にブロードな回折が残っていることか ら，ケージを構成する $\mathrm{Ge}$ 同士の結合は切断されず

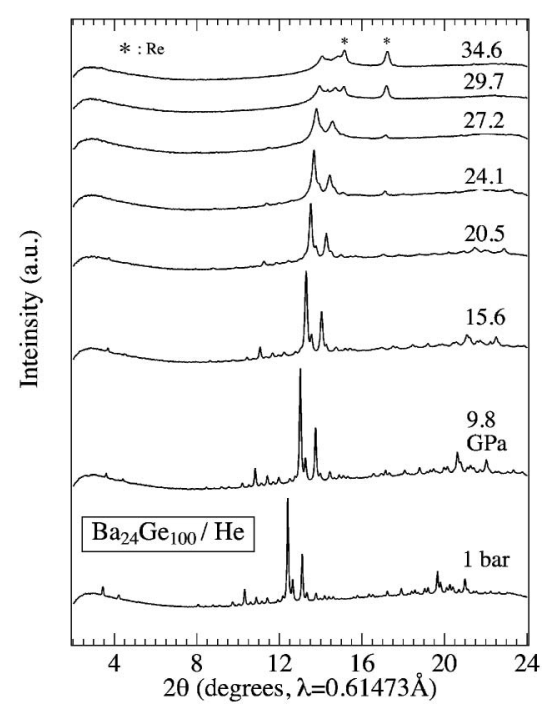

Fig. 4. X-ray diffraction patterns of $\mathrm{Ba}_{24} \mathrm{Ge}_{100}$ with helium pressure medium in various pressure. Asterisks indicate diffraction peaks of rhenium gasket. 
に残されたまま，ケージが不規則に歪んだり変形す るなどしているのではないかと考えている。

長周期構造の乱れが起こるまでの圧力領域につい て状態方程式 (equation of state, EoS)を求めるため, 圧力と単位胞体積の関係を三次の Birch-Murnaghan の式でフィッティングし [17], 測定誤差を考慮した 最小二乗法の重み付きカイ二乗 $\left(\chi_{\mathrm{w}}^{2}\right)$ を求めた。 その結果, $\chi_{\mathrm{w}}^{2}$ は 1 から大きく離れ, 常圧から $10 \mathrm{GPa}$ までの圧力領域を一本の EoS 曲線ではフィ ッティングできないことが分かった。そこで常圧側 と $10 \mathrm{GPa}$ 側からそれぞれ $\chi_{\mathrm{w}}^{2}$ が 1 付近に収まる領 域を求めたところ，4.5-5.0 付近を境に二本の Birch-Murnaghan の式でフィッティングが可能であ ることが分かった。これを元に求めた EoS を表し たのが Fig. 5 である。4.5-5.0 GPa 付近から体積が わずかに縮みにくくなり，体積弾性率の異なる別の EoS に移行していることが分かる。

この変化が起こる $\mathrm{Ba}_{24} \mathrm{Ge}_{100}$ の単位胞体積（約 $\left.2830 \AA^{3}\right)$ は, $\mathrm{Ba}_{24} \mathrm{Si}_{100}$ の常圧における単位胞体積 $\left(2784 \AA^{3}\right)$ に近い。これは, もともと体積が大きく $\mathrm{Ba}$ イオンを内包するケージ内に余裕のある $\mathrm{Ba}_{24} \mathrm{Ge}_{100}$ が，圧力上昇によるケージの縮小でその 余裕をなくして $\mathrm{Ba}_{24} \mathrm{Si}_{100}$ と類似の状態となり, 別 の $\mathrm{EoS}$ へと移行したものと推察される。これは， 圧力の上昇に伴い, $200 \mathrm{~K}$ 付近での相転移が抑制さ れる傾向を示すことや， $T_{\mathrm{c}}$ が上昇することなどと

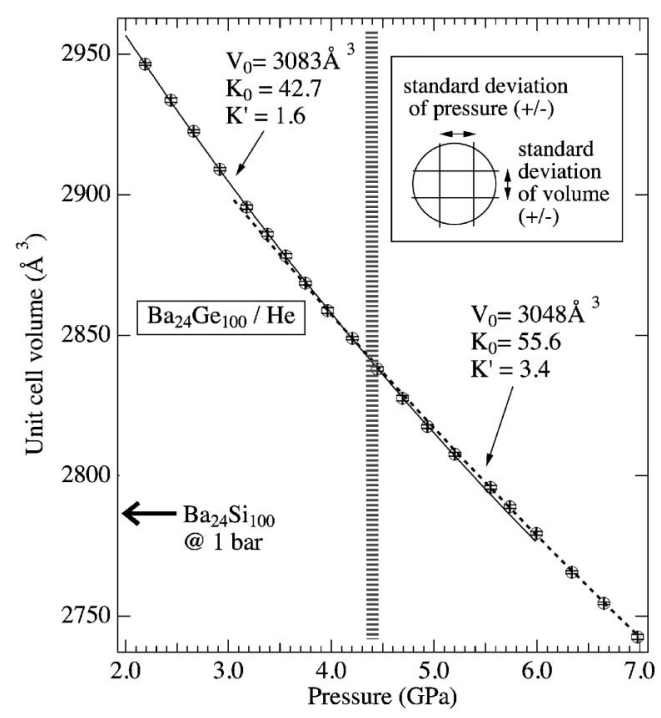

Fig. 5. Unit cell volume of $\mathrm{Ba}_{24} \mathrm{Ge}_{100}$ in a function of pressure and Birch-Murnaghan EoS curves.
対応していると考えられる。このようなわずかな $\operatorname{EoS}$ の変化は，ヘリウム圧力媒体を用いた精密な 測定により，効果的に見いだすことができた。

\section{$3.3 \mathrm{Ba}_{24} \mathrm{Ge}_{100}$ の低温高圧 X 線回折測定}

上記のように, $\mathrm{Ba}_{24} \mathrm{Si}_{100}$ と $\mathrm{Ba}_{24} \mathrm{Ge}_{100}$ の物性の違 い, 特に高圧下に抢ける挙動の差異について, ヘリ ウム圧力媒体を用いた室温高圧 X 線回折で得られ た EoS から考察したが，いずれも低温物性を室温 の実験から議論をしている点では問題がある。そこ で，低温高圧実験が必要となる。しかしながら，圧 力媒体の固化 ·硬化による静水圧性の問題は, 低温 高圧実験では一層顕著となる。そこで, ヘリウム圧 力媒体が低温高圧実験でも有効であるかを調べる意 味も含め, $\mathrm{Ba}_{24} \mathrm{Ge}_{100}$ の粉末低温高圧 $\mathrm{X}$ 線回折測定 を行った。

高圧装置には $\mathrm{Cu}-\mathrm{Be}$ 製クランプ式の $\mathrm{DAC}$, 圧力 媒体に $180 \mathrm{MPa}$ のヘリウムを充填し, ヘリウムガ 又駆動のメンブレンを用いて約 $3 \mathrm{GPa}$ まで加圧し た。圧力はルビ一蛍光法により測定し, 高圧 X 線 回折実験は SPring-8 BL10XU および KEK-PF BL$18 \mathrm{C}$ で行った。

$\mathrm{Ba}_{24} \mathrm{Ge}_{100}$ の回折パターンの約 $1.5 \mathrm{GPa}$ での温度 変化をFig. 6 に示す。 $5 \mathrm{~K}$ に扮いても，250 K とほ ぼ同等のシャープな回折図形を得ることができ，低 温高圧下に抢けるへリウムの静水圧効果が確認され た。電気抵抗の変化から相転移が示唆されている温 度 $T_{\mathrm{s} 1}$ および $T_{\mathrm{s} 2}$ の前後において, 回折図形に大き な変化はなかった。格子定数の温度依存性を求めた ところ, 常圧では明らかに温度 $T_{\mathrm{s} 1}$ および $T_{\mathrm{s} 2}$ の前 後で有意な変化が見られ, 従来の報告 $[10]$ と整合し た。しかし，低温高圧下では圧力の制御が難しく $( \pm 0.1 \mathrm{GPa}$ 以下の制御は困難 $)$, 温度依存性の傾向 を見極めることはできなかった。これらより，温度 $T_{\mathrm{s} 1} \sim T_{\mathrm{s} 2}$ の領域では, 基本構造は変わらないが構造 上の変化として観測しうる何らかの転移現象が起き ているということができる。さらに現在, 構造パラ メーターの解析をリートベルト解析により現在進め て抢り，以下にその preliminary な結果を示す。

既に述べたように, $\mathrm{Ba}_{24} \mathrm{Ge}_{100}$ には三つの原子位 置があるが，その一つで open cage に入っている $\mathrm{Ba}(3)$ は, 常圧 $80 \mathrm{~K}$ 付近で非対称的なラットリン グ振動をしていることが報告されている。ここでは, 低温高圧 X 線回折により得られた回折パターンを 解析し, このような $\mathrm{Ba}(3)$ のラットリング挙動と 温度・圧力の関係を調べた。リートベルト解析には 


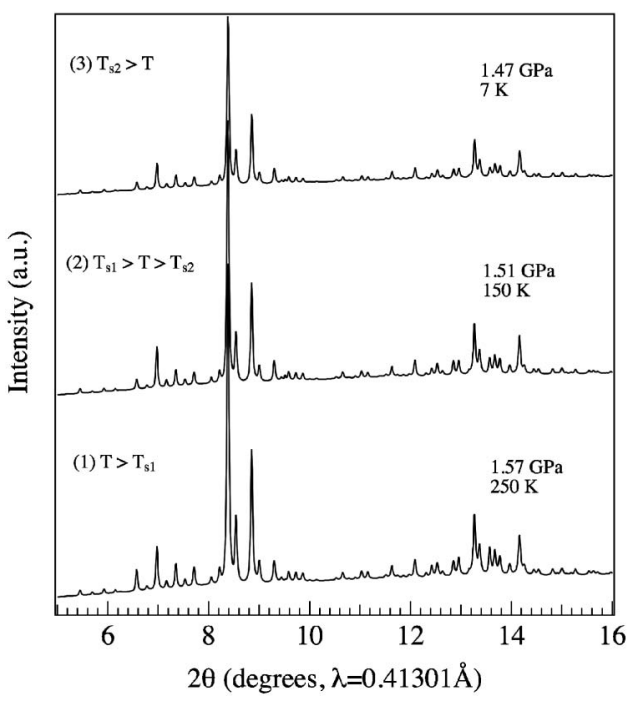

Fig. 6. X-ray diffraction patterns of $\mathrm{Ba}_{24} \mathrm{Ge}_{100}$ at 250, 150 and $7 \mathrm{~K}$ under the pressure near $1.5 \mathrm{GPa} . T_{\mathrm{s} 1}$ and $T_{\mathrm{s} 2}$ correspond to the transition temperatures, which have been reported previously [11].

RIETAN-FP [18]を用い, $\mathrm{Ba}(3)$ の存在位置を $\mathrm{Ba}$ $\left(3 \_1\right): 12 d(1 / 8, y, z)$ 以外にもう 1 か所 $\mathrm{Ba}\left(3 \_2\right)$ : $12 d(x, y, z)$ に仮定し, 原子変位パラメーターは全 ての原子で同じであると仮定して解析を行った。ラ フな計算ではあるが，これにより， $\mathrm{Ba}(3)$ の変動が $\mathrm{Ba}\left(33_{-} 2\right)$ の $\mathrm{Ba}\left(3_{-}\right.$1) からのずれとして表現される。

Fig. 7 に $3.2 \mathrm{GPa}, 7.6 \mathrm{~K}$ で得られた粉末 $\mathrm{X}$ 線回 折パターンとその解析結果を示す。また, $\mathrm{Ba}(3$ 1) と $\mathrm{Ba}\left(3 \_2\right)$ の間の $x$ 座標のずれについて, 各温 度圧力でプロットしたのが Fig. 8 である。これに よれば, $0.8 \mathrm{GPa}$ では $100 \mathrm{~K}$ 付近で $\mathrm{Ba}(3)$ の二つの 原子位置の $x$ 座標の差 $\Delta x=x\left(\mathrm{Ba} 3 \_1\right)-x\left(\mathrm{Ba} 3 \_2\right)$ が大きくなっていることが分かる。これは，基本的 に常圧に打ける MEM 解析の結果に対応しており, 低温で相転移が現れることと, 超伝導転移温度 $T_{\mathrm{c}}$ が低く押さえられていることに対応していると考え られる。圧力が $1.5 \mathrm{GPa}$ に上昇すると，この $\Delta x$ の 増大は抑制されて低温側にシフトする。そして,

$2.1 \mathrm{GPa}$ 以上では, もはや $\Delta x$ の増大は見られない。 これらは, 圧力上昇により低温での相転移が抑制さ れ， $T_{\mathrm{c}}$ の上昇が見られることに対応していると考 えられ，それが $\mathrm{Ba}(3)$ 原子のラットリングに関係 している，すなわち $\mathrm{Ba}(3)$ をめぐる電子ーフォノ ン相互作用の影響を強く受けていることが示唆され ている。

このような解析に耐え得る回折パターンが低温高

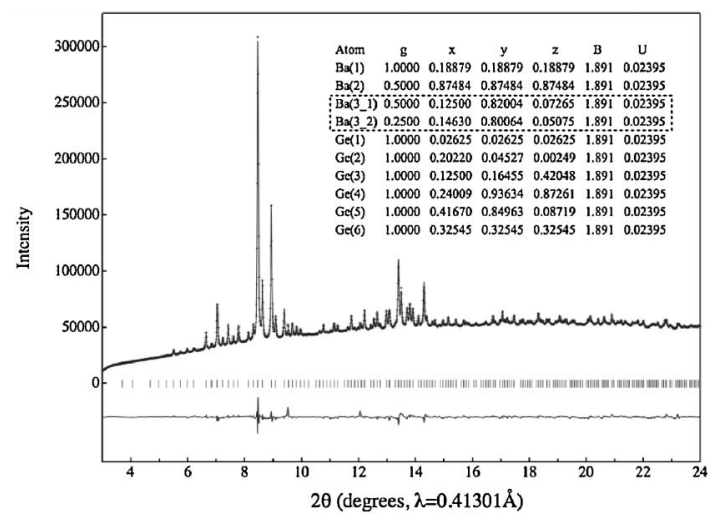

Fig. 7. The example of the x-ray diffraction profile of $\mathrm{Ba}_{24} \mathrm{Ge}_{100}$ obtained at $3.2 \mathrm{GPa}$ and $7 \mathrm{~K}$ (cross marks), and the profile calculated using Rietveld refinement (line). Two positions of $\mathrm{Ba}(3)$ atom, $\mathrm{Ba}\left(3_{-} 1\right)$ and $\mathrm{Ba}\left(3_{-} 2\right)$, were presumed. Thick marks for the Bragg peak positions and the difference profile plot are also displayed.



Fig. 8. Difference of the $x$-coordinate of two $\mathrm{Ba}(3)$ positions, $\Delta x=x\left(\mathrm{Ba}_{-}{ }_{1}\right)-x\left(\mathrm{Ba}_{-}{ }_{2}\right)$, of $\mathrm{Ba}_{24} \mathrm{Ge}_{100}$ calculated by Rietveld refinement.

圧条件でも得られたのは，ヘリウムが低温高圧下で も静水圧性の高い圧力媒体であることを示している と考えている。

\section{4. おわりに}

ヘリウム圧力媒体を使うことで静水圧性の高い実 験を行い, その精密な解析から, 従来は埋もれてい た情報が引き出せることを，いくつかの例を用いて 示した。構造的異方性の大きい配列ナノ空間物質は, 特にその影響が顕著である。圧力依存性を調べるこ とがその物質の物性解明に有効であることが認識さ れ，DACの利用も普及している。DACの普及と 同じようにガス圧媒体の利用が広がれば，さらに見 
直されるデータがいくつも現れるだろう。

その一方で，ヘリウム圧力媒体を用いることによ るデメリットもある。例えば, 物質によってはへリ ウム原子が物質の構造の空隙内に入り込み，その物 質本来の挙動とは異なるデータが観測されることが ある。 $\mathrm{SiO}_{2}$ ガラスの体積の圧力依存性を $\mathrm{X}$ 線回折 により測定すると, ヘリウム圧力媒体中では 2 割以 上も大きな体積が観測され, $10 \mathrm{GPa}$ では $1 \mathrm{~mol} \mathrm{SiO}_{2}$ に 1.0-2.3 mol のヘリウムが溶解していると推定さ れた $[19]$ 。類似の挙動は, $\mathrm{SiO}_{2}$ クラスレートの実 験でも観察されている $[20]$ 。しいながら，これら の情報は物質の構造と物性理解に大きな情報を与え るほか，新たな物質創成の可能性も示唆する情報と なるため, 必ずしも否定的にとらえる必要はない。

いずれにしても, 配列ナノ空間物質の高圧研究で は、ヘリウムをはじめとしたガス圧力媒体を用いる ことで新たに見いだされる事象は少なくないだろう。 筆者の所属機関でも共同研究の形で多方面からのガ ス充填の依頼を受けているので, 関心ある方はぜひ お声をかけて頂ければと考えている。

\section{謝 辞}

本研究の一部は, 文部科学省科学研究補助金特定 領域研究「配列ナノ空間を利用した新物質科学一ユ ビキタス元素戦略」の助成を得て行われました（研 究課題番号 20045019 および 22013021)。試料を提 供してくださった木村薰教授 (東大新領域), 兵藤 宏博士（東大新領域, 現東京理大), 谷垣勝巳教授 (東北大院理), 熊代良太郎准教授 (東北大院理), 討論で貴重なコメントを頂きました白井光雲准教授 （阪大産研）に深く謝意を表します。また，X線回 折測定実験は, 高エネルギー加速器研究機構物質構 造科学研究所放射光共同利用実験（課題番号 2010G519）抢よび SPring-8 量子ビーム施設震災優 先枠（課題番号 2011A1943）を利用して行われま した。実験をお手伝い頂いた今枝佑太氏, 中本环磨 氏, 船橋健太氏, 久米徹二准教授 (以上, 岐阜大工), 亀卦川卓美講師 (高エネ機構物構研), 平尾直久博 士 (JASRI), 大石泰生博士（JASRI）に感謝いた します。

\section{参考文献}

[1] A. Sano-Furukawa, H. Kagi, T. Nagai, S. Nakano, S. Fukura, D. Ushijima, R. Iizuka, E. Ohtani, T. Yagi: Am. Mineral., 94, 1255 (2009).

[2] K. Matsuishi, T. Ishihara, S. Onari, Y.H. Chang, C.H. Park: Phys. Stat. Sol. (b), 241, 3328 (2004).
[3] K. Takemura, K. Sato, H. Fujihisa, M. Onoda: Nature, 423, 971 (2003).

[4] M.I. Eremets, V.V. Struzhkin1, H.-K. Mao, R.J. Hemley: Science, 293, 272 (2001).

[5] K. Shimizu, M. Kaneshige, Y. Hashimoto, T. Nagatochi, H. Hyodo, K. Kimura: Physica C, 470, S631 (2010).

[6] 藤井譲, 藤井暁, 森嘉久, 財部健一, 兵藤宏,

木村薰 : 第 48 回高圧討論会要旨集, 1P12, p. 86 (2007).

[7] A. Polian, J.C. Chervin, P. Munsch, M. Gauthier: J. Phys. Conf. Ser., 121, 042017 (2008).

[8] K. Takemura, P.Ch. Sahu, Y. Kunii, Y. Toma: Rev. Sci. Instrum., 72, 3873 (2001).

[9] K. Shirai, H. Dekura, Y. Mori, Y. Fujii, H. Hyodo, K. Kimura: J. Phys. Soc. Jpn., 80, 084601 (2011).

[10] T. Rachi, K. Tanigaki, R. Kumashiro, K. Kobayashi, H. Yoshino, K. Murata, H. Fukuoka, S. Yamanaka, H. Shimotani, T. Takenobu, Y. Iwasa, T. Sasaki, N. Kobayashi, Y. Miyazaki, K. Saito: J. Phys. Chem. Solids, 67, 1334 (2006).

[11] S. Paschen, V.H. Tran, M. Baenitz, W. Carrillo-Cabrera, Y. Grin, F. Steglich: Phys. Rev. $\mathrm{B}, \mathbf{6 5}, 134435$ (2002).

[12] W. Carrillo-Cabrera, H. Borrmann, S. Paschen, M. Baenitz, F. Steglich, Y. Grin: J. Solid State Chem., 178, 715 (2005).

[13] T. Rachi, H. Yoshino, R. Kumashiro, M. Kitajima, K. Kobayashi, K. Yokogawa, K. Murata, N. Kimura, H. Aoki, H. Fukuoka, S. Yamanaka, H. Shimotani, T. Takenobu, Y. Iwasa, T. Sasaki, N. Kobayashi, Y. Miyazaki, K. Saito, F. Guo, K. Kobayashi, K. Osaka, K. Kato, M. Takata, K. Tanigaki: Phys. Rev. B, 72, 144504 (2005).

[14] F.M. Grosche, H.Q. Yuan, W. CarrilloCabrera, S. Paschen, C. Langhammer, F. Kromer, G. Sparn, M. Baenitz, Y. Grin, F. Steglich: Phys. Rev. Lett., 87, 247003 (2001).

[15] H. Shimizu, T. Fukushima, T. Kume, S. Sasaki, H. Fukuoka, S. Yamanaka: J. Appl. Phys., 101, 113531 (2007).

[16] H. Shimizu, R. Oe, S. Ohno, T. Kume, S. Sasaki, K. Kishimoto, T. Koyanagi, Y. Ohishi: J. Appl. Phys., 105, 043522 (2009).

[17] R.J. Angel: in High-Temperature and High Pressure Crystal Chemistry, eds. R.M. Hazen, R.T. Downs (Mineralogical Society of America and Geochemical Society, Chantilly, 2001), Reviews in Mineralogy and Geochemistry, Vol. 41, Chap. 2, pp. $35-60$.

[18] F. Izumi, K. Momma: Solid State Phenom., 130, 15 (2007).

[19] T. Sato, N. Funamori, T. Yagi: Nature Commun., 2, 345 (2011).

[20] T. Yagi, E. Iida, H. Hirai, N. Miyajima, T. Kikegawa, M. Bunno: Phys. Rev. B, 75, 174115 (2007).

[2011 年 12 月 12 日受付, 2011 年 12 月 22 日受理] (C) 2012 日本高圧力学会 